\title{
$\mathrm{Al}$ 원형관의 2 축압축 변형특성에 관한 연구
}

\author{
유종근 ${ }^{1} \cdot$ 김기주 $^{2} \cdot$ 원시태\# $^{\#}$
}

\section{Biaxial Compressive Deformation Characteristics of Round Aluminum Pipe}

\author{
C. K. Yoo, K. J. Kim, S. T. Won \\ (Received November 15, 2011 / Revised December 26, 2011 / Accepted January 4, 2012)
}

\begin{abstract}
To examine the deformation characteristics of round aluminum pipe under biaxial compression, a horizontal biaxial compression die was fabricated. The change of material properties, punch load and deformation behavior were monitored in experiments using various compressive deformation rates in the range of $1 \mathrm{~mm} / \mathrm{min}$. $\sim 400 \mathrm{~mm} / \mathrm{min}$. The tensile and compressive strains were estimated from Vickers microhardness results. The punch load and deformation characteristic of the round aluminum pipes were found to change greatly at a deformation rate of about $200 \mathrm{~mm} / \mathrm{min}$. The punch load decreased with increasing compressive deformation rate. Results of numerical simulation using Deform-2D were in good agreement with experimental results, and the measured hardness variation with the strain variation was predicted well by the simulation.
\end{abstract}

Key Words : Deformation Rate, Biaxial, Compressive, Deformation, Aluminum, Round Pipe

\section{1. 서 론}

원형관은 배관과 기계구조물 및 각종 설비의 용도로 많이 사용되고 있다. 이러한 용도의 원형 관의 2 차 가공 및 성형은 굽힘 가공, 단축 압축 가공이 종래의 주된 가공법이었다. 이 보다 특수 한 2차 가공법으로 원형관의 2축 압축가공이 고 려될 수 있다[1 5]. 따라서 본 연구에서는 2축 압 축을 받는 $\mathrm{Al}$ 원형관의 변형특성을 검토하기 위 하여 단동 2축 압축 시험 금형을 제작하고, 압축 속도의 크기와 윤활유의 종류에 따른 2축 압축변 형 특성을 검토하였다.

\section{2. 시험장치 및 시험 방법}

1. 뉴테크

2. 서정대학교,자동차과

\# 교신저자: 서울과학기술대학교,제품설계금형공학과

E-mail: stwon370@seoultech.ac.kr

\section{1 시험장치}

원형관의 2축 압축 시험은 Fig. 1 과 같은 단동 가경식(單動可傾式) 2축 압축시험 금형을 제작하 여 사용하였다[2]. 본 시험 금형은 가경식으로 상, 하형의 회전 조절에 의해서 각도 변화가 $45^{\circ}$ (정사 각) 에서 최대 $70^{\circ}$ (장방형) 범위까지 시험할 수 있 다. 본 실험은 $45^{\circ}$ 로 동일한 압축비(정사각)로 시 험하였고, 시험편에 작용하는 2 축 하중의 하중 작 용 상태는 Fig. 2와 같다.

\section{2 시험재료 및 시험편 형상}

본 실험에는 $\mathrm{Al}$ 원형관을 사용하였다. 시험편 소재의 화학성분은 Table 1 과 같고, 기계적 성질은 Table 2와 같다. 시험편 형상과 규격은 Fig. 3 과 같다. 


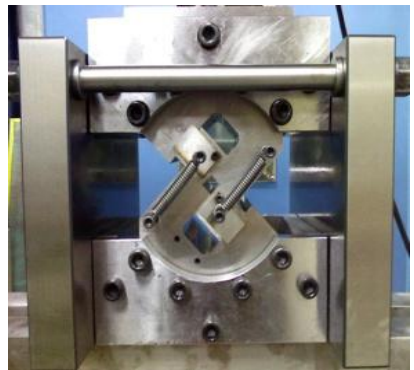

Fig. 1 Biaxial compression experimental apparatus
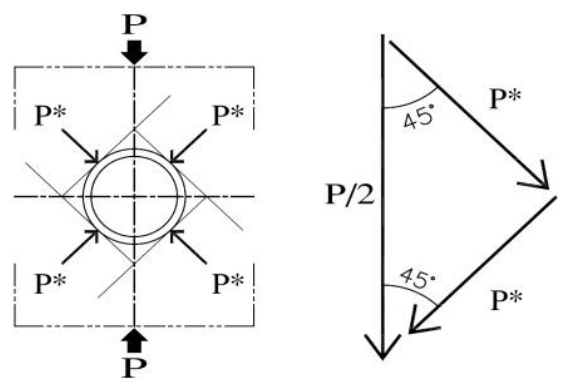

Fig. 2 Biaxial compression load sate

Table 1 Chemical composition (\%)

\begin{tabular}{c|c|c|c|c|c|c}
\hline \hline Material & $\mathrm{Cu}$ & $\mathrm{Al}$ & $\mathrm{Ti}$ & $\mathrm{Mn}$ & $\mathrm{Zn}$ & $\mathrm{Pb}$ \\
\hline Al & $\mathbf{0 . 0 4 7}$ & Over & $\mathbf{0 . 0 0 8}$ & $\mathbf{0 . 0 0 2 3}$ & $\mathbf{0 . 0 7 3}$ & $\mathbf{0 . 0 0 1 7}$ \\
\hline
\end{tabular}

Table 2 Mechanical properties

\begin{tabular}{c|c|c|c|c|c}
\hline \hline Material & $\sigma(\mathrm{MPa})$ & $\varepsilon(\%)$ & $\mathrm{C}(\mathrm{MPa})$ & $\mathbf{n}$ & $\mathbf{H}_{\mathrm{mv}}$ \\
\hline Al & $\mathbf{2 1 2 . 4}$ & $\mathbf{1 0 . 0}$ & 196 & $\mathbf{0 . 2 1}$ & $\mathbf{8 9 . 3}$ \\
\hline
\end{tabular}

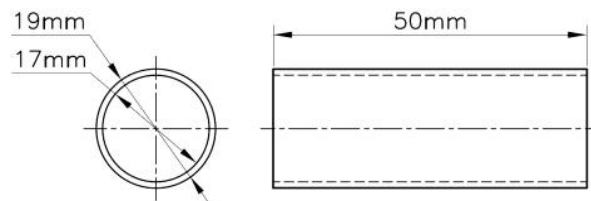

Fig. 3 Geometry of test specimen

\section{3 시험조건 및 방법}

본 시험 금형(Fig. 1)에서 시험편이 장착되는 부 분과 시험편의 접촉표면에는 윤활을 실시하였고, 윤활유의 종류와 점도는 Table 3 과 같다.

압축속도는 $1 \mathrm{~mm} / \mathrm{min} .450 \mathrm{~mm} / \mathrm{min}$. 범위에서 몇 단계로 나누어 2축 압축 변형특성을 비교하였다. 또한 2축 압축 응력-변형율 특성곡선에서 주요 지 점의 단면 형상변화의 특성을 육안으로 쉽게 구 분할 수 있도록 하였고, 압축속도의 크기에 의한 하중과 변위에 따른 변형특성을 규명하였다. 또한
Table 3 Viscosity coefficient of lubrication oils

\begin{tabular}{c|c}
\hline \hline Lubrication oils & Visosity coefficient $(\mathbf{C P})$ \\
\hline Soy bean oil & 70 \\
\hline MD-501 & 100 \\
\hline EP gear oil & 410 \\
\hline MSD-550 & 635 \\
\hline Ultra D-4080 & 1020 \\
\hline
\end{tabular}

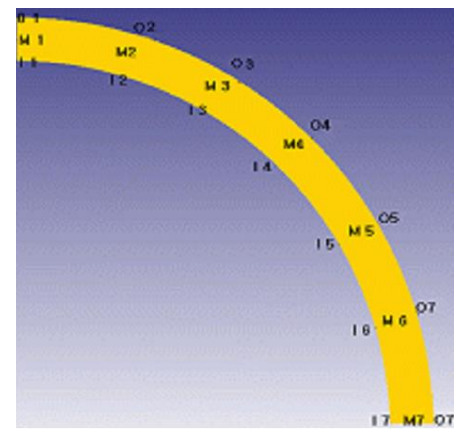

Fig. 4 Micro Vickers measure points

변형과정에 따른 인장과 압축 변형량의 평가를 Deform-2D에 의한 해석을 실시하여 실험결과에 대한 검증 및 보완을 하였다.

각 단계에서 압축 변형된 시험편은 마이크로 비커스 경도계를 사용하여 Fig. 4에서 나타낸 것처 럼 시험편의 초기 특정 위치를 지정하고 경도값 을 측정(시험하중 $50 \mathrm{~g}$ )하여 각 변형 단계에서의 경도값을 조사하였다.

\section{3. 시험결과 및 고찰}

Fig. 5는 압축속도 $10 \mathrm{~mm} / \mathrm{min}$. 의 2축 압축 과정에 서 펀치하중과 펀치 스트로크(변형)의 특성을 나 타낸 것이다. 그래프에 첨부된 단면 사진은 그 지 점에서의 변형된 $\mathrm{Al}$ 원형관의 단면 상태을 나타 낸다. 그래프의 특성곡선을 살펴보면 변형초기에 는 2축 압축 시험 장치의 다이면이 원형관에 점 접촉한 후 일정하중 $(6 \mathrm{kgf})$ 의 1 차 변형 일정구간 $(0.0 \sim 0.4 \mathrm{~mm})$ 이 나타나고, 이후 면 접촉이 시작되는 $0.4 \sim 0.7 \mathrm{~mm}$ 구간에서 급격한 1 차 하중증가 구간이 발생한다. 한편 다이와 시험편의 면 접촉이 본격적 으로 시작되는 스트로크 $0.7 \mathrm{~mm} 1.7 \mathrm{~mm}$ 위치에서 2 차 변형 일정구간이 발생한다. 이 지점을 지나면

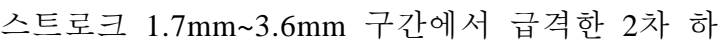
중 증가구간이 발생한다. 이때 2 차 하중의 증가구 간은 면 접촉이 상당히 진전된 상태이다. 그리고 


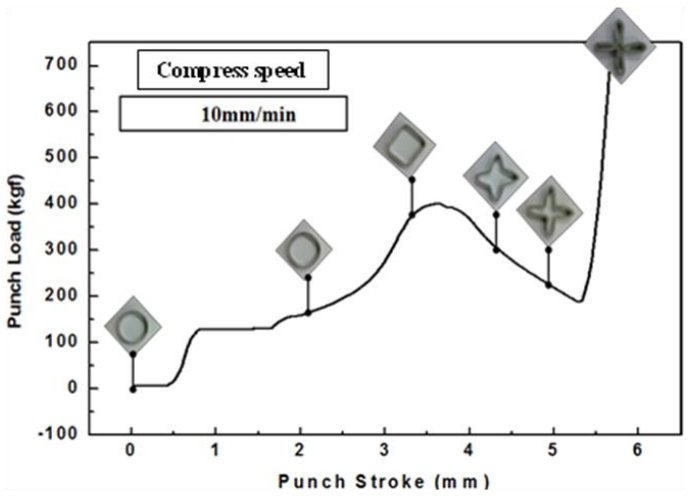

Fig. 5 The relation between punch load-stroke curve and Al circular pipe deformed shapes

2차 하중 증가구간을 지나면서 원형단면 형상이 본격적으로 사각단면 형상으로 변형되기 시작한 다. 한편 하중 최대 점 $(395 \mathrm{kgf})$ 은 사각 단면 형상 에서 내측으로 좌굴이 약간 시작된 스트로크 $3.6 \mathrm{~mm}$ 부근에서 발생한다. 이후 원형관의 내측으 로 계속 변형되어 중심부분에서 4 면이 접촉하기 직전인 스트로크 $5.3 \mathrm{~mm}$ 위치까지 하중감소가 나 타난다. 이 지점을 지나면 다시 급격한 3 차 하중 의 증가가 나타나는 전형적인 변형특성이 나타 난다.

Fig. 6은 5종류의 압축속도에 대한 시험 결과를 나타낸 것이다.

압축속도 $1 \sim 200 \mathrm{~mm} / \mathrm{min}$. 에서는 1차 하중 증가 구간(스트로크 $0.4 \sim 0.7 \mathrm{~mm}$ )이 뚜렷하게 나타나고 있다. 그러나 속도 $200 \mathrm{~mm} / \mathrm{min}$. 이상에서는 $\mathrm{S}$ 자형 1차 상승 구간(스트로크0.3 0.9mm)을 나타내고 속 도 $300 \mathrm{~mm} / \mathrm{min}$. 과 $400 \mathrm{~mm} / \mathrm{min}$. 에서는 완만한 상승 곡선(스트로크 $0.2 ~ 1.2 \mathrm{~mm}$ )의 특징을 보이고 있다. 스트로크 $0.15 \sim 0.45 \mathrm{~mm}$ 구간의 특징을 보면 속도 가 빠를수록 1 차 하중증가가 빠르고 크게 나타 난다. 이는 변형되기 전의 원형관의 저항력에 기 인하는 것으로 속도가 빠르면 빠를수록 반력(충 격반력)이 커져서 나타나는 것으로 생각된다. 이 저항력이 꺽이면 항복과 같은 현상으로 원형관의 반력의 영향보다 속도에 따른 운동에 너지 $\left(\mathrm{E}=1 / 2 \mathrm{mv}^{2}\right)$ 의 영향이 커져 스트로크 $0.7 \sim 1.1 \mathrm{~mm}$ 에 서는 역으로 속 도가 빠를수록 하중이 낮아진다. 변형은 계속되어 스트로크 $1.2 ~ 2.8 \mathrm{~mm}$ 구간에서는 속도에 따른 변형 하중의 차이가 거의 없는 완만 한 상승 곡선을 나타낸다. 스트로크 $3.0 \mathrm{~mm}$ 부근에 서 원형관은 4 각형상으로 되고 이후 좀 더

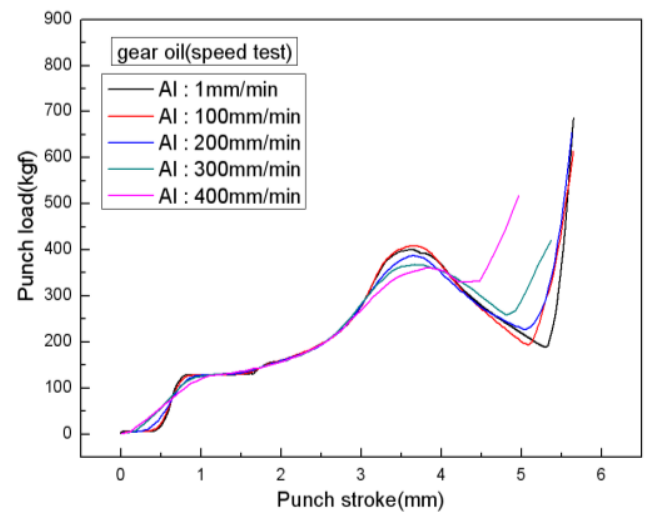

Fig. 6 The characteristic of punch load-stroke curve on various compressive strain rates

급격한 하중 증가가 나타난다. 이 구간이 2차 하 중 증가 구간이다. 스트로크 $3.5 \mathrm{~mm}$ 부근에서 1 차 최대 하중점을 나타낸다. 이 지점에서는 속도가 빠를 수록 낮은 하중을 나타내고 있다 이렇게 속 도에 따라 1 차 최대 하중이 달라지는 원인은 속 도의 제곱에 비례하는 운동에너지에 기인하는 것 으로 생각된다. 2축 압축 속도가 빠를수록 운동에 너지가 커지므로 빠른 속도에서는 낮은 하중을 나타낸다. 1 차 하중 최대 점을 지나면 $\mathrm{Al}$ 원형관 은 내측으로 더욱 크게 좌굴 되면서 비교적 급격 한 하중 감소를 나타낸다. 이후 원형관은 내측으 로 좌굴되어 내측의 4 면이 접촉 되면서 급격한 3 차 하중 증가를 나타낸다. 그러나 3 차 하중증가의 시작점은 속도에 따라 각기 다른 위치에서 시작 되고 있다. 3 차 하중 증가의 시작점은 속도가 빠 를수록 빨리 진행되고 있는데 이 또한 속도에 비 례한 운동에너지의 영향으로 생각된다. 예를들어 압축속도 $400 \mathrm{~mm} / \mathrm{min}$.은 스트로크 $4.4 \mathrm{~mm}$ 지점에 서 시작되고 있다. 그런데 압축속도가 제일 낮은 $1 \mathrm{~mm} / \mathrm{min}$.은 스트로크 $5.3 \mathrm{~mm}$ 지점에서 시작되고 있 다. 결국 압축속도 $400 \mathrm{~mm} / \mathrm{min}$.은 큰 운동에너지로 압축속도 $1 \mathrm{~mm} / \mathrm{min}$.에 비해 $0.9 \mathrm{~mm}$ 만큼 더 많이 압 축시킨 결과이다. 이와 같이 원형관의 2축 압축변 형에서 압축속도에 따른 변형특성 결과는 주목할 만한 특징을 나타내고 있다.

Fig. 7은 압축속도 $1 \mathrm{~mm} / \mathrm{min}$.조건에서 윤활유의 종류에 따른 실험 결과이다. 원형관에 펀치가 접 촉되어 스트로크 $0.3 \mathrm{~mm}$ 지점까지 1 차 하중 증가 가 나타난다. 윤활유에 따른 하중의 영향은 거의 나타나지 않는다. 스트로크 $0.3 \sim 1.1 \mathrm{~mm}$ 구간은 일정 한 하중구간을 나타내고 스트로크 $1.1 \mathrm{~mm}$ 부터 완만 


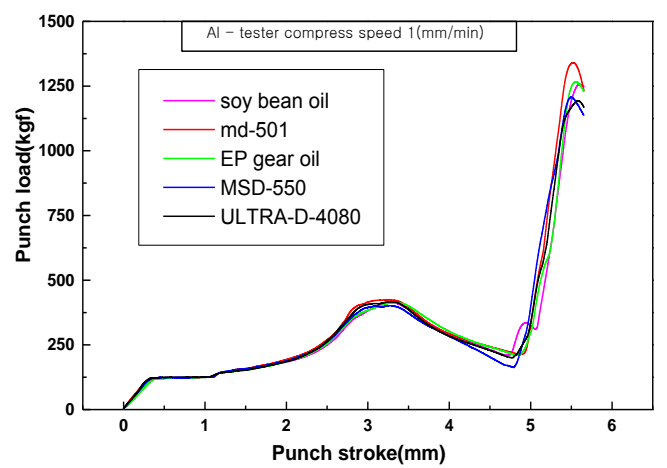

Fig. 7 The characteristic of punch load-stroke curve on lubrication compressive strain rates( $1 \mathrm{~mm} / \mathrm{min}$.)

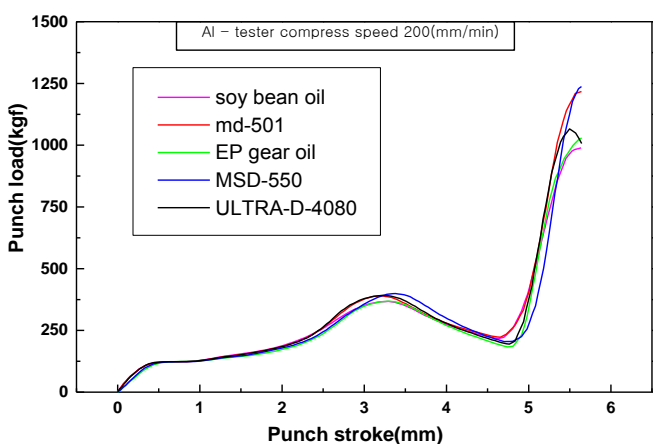

Fig. 8 The characteristic of punch load-stroke curve on lubrication compressive strain rates $(200 \mathrm{~mm} / \mathrm{min}$.)

한 하중 증가를 나타낸다. 스트로크 $2.7 \mathrm{~mm}$ 지점에 서 원형관은 4 각으로 되고 2 차 하중 증가가 급격 하게 나타나고 있다. 스트로크 $3.2 \mathrm{~mm}$ 부근에서 1 차 최대 하중을 나타내고 있고, 미미하지만 윤활 유의 점도가 낮을수록 높은 하중을 나타내고 있 으나, 윤활유에 의한 하중의 차이는 그리 크지 않 음을 알 수 있다. 스트로크 $3.2 \mathrm{~mm}$ 부근을 지나면 원형관은 내측으로 더욱 좌굴되어 1 차 하중 감소 구간이 나타난다. 스트로크 $4.8 \mathrm{~mm}$ 부근에서 원형 관은 내측 4점 접촉 상태가 되어 급격하게 3 차 하중 증가가 나타난다. 3 차 하중 증가의 시작점은 거의 같은 시점이고 점도가 낮을수록 약간 높은 하중을 나타내고 있다.

Fig. 8은 압축속도 $200 \mathrm{~mm} / \mathrm{min}$.조건에서 윤활유의 종류를 다르게 한 실험결과이다. 원형관에 접촉되 어 스트로크 $0.4 \mathrm{~mm}$ 부근까지 1 차 하중 증가를 나 타낸다. 여기서도 윤활유 종류에 의한 하중의 차이 는 아주 미약하다. 스트로크 $0.4 \sim 1.1 \mathrm{~mm}$ 구간은 일 정한 하중을 나타내고, 스트로크 $1.1 \mathrm{~mm}$ 에서 완만한

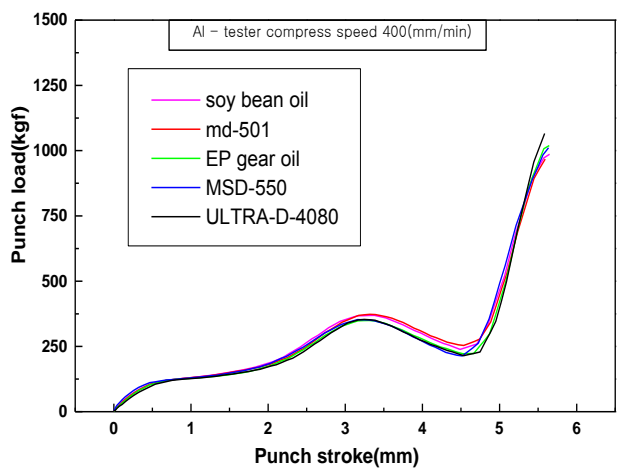

Fig. 9 The characteristic of punch load-stroke curve on lubrication compressive strain rates $(400 \mathrm{~mm}$ /min.)

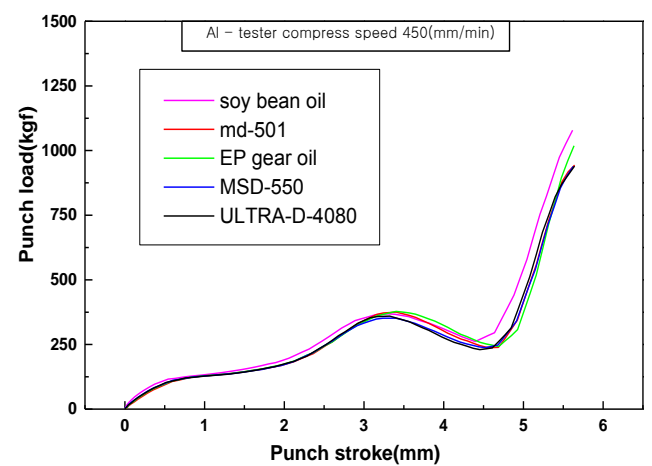

Fig.10 The characteristic of punch load-stroke curve on lubrication compressive strain rates $(450 \mathrm{~mm} /$ min.)

하중 증가가 시작된다. 스트로크 $2.7 \mathrm{~mm}$ 지점에서 원형관은 4 각으로 되고 2 차 하중 증가는 완만하 게 나타나고 있다.

스트로크 $3.3 \mathrm{~mm}$ 부근에서 1 차 최대 하중을 나 타내고 윤활유 점도에 따른 하중 특성도 뚜렷하 지 않고 하중의 차이도 작다. 스트로크 $3.3 \mathrm{~mm}$ 부 근을 지나면 원형관은 내측으로 더욱 좌굴되어 1 차 하중 감소를 나타낸다. 스트로크 $4.8 \mathrm{~mm}$ 부근 에서 원형관은 내측 4점 접촉 상태가 되어 급격 하게 3 차 하중 증가를 나타낸다. 3 차 하중 증가의 시작은 거의 같은 시점이고 점도가 낮을수록 미 약하지만 약간 높은 하중을 나타내고 있다.

Fig. 9는 압축속도 $400 \mathrm{~mm} / \mathrm{min}$.에서 윤활유의 종 류를 다르게 한 실험 결과이다. 원형관에 접촉되 어 스트로크 $0.7 \mathrm{~mm}$ 부근까지 1 차 하중 증가를 나 타낸다. 여기서도 윤활유의 종류에 의한 하중의 차이는 아주 작게 나타나고 있다. 스트로크 $0.7 \mathrm{~mm}$ 

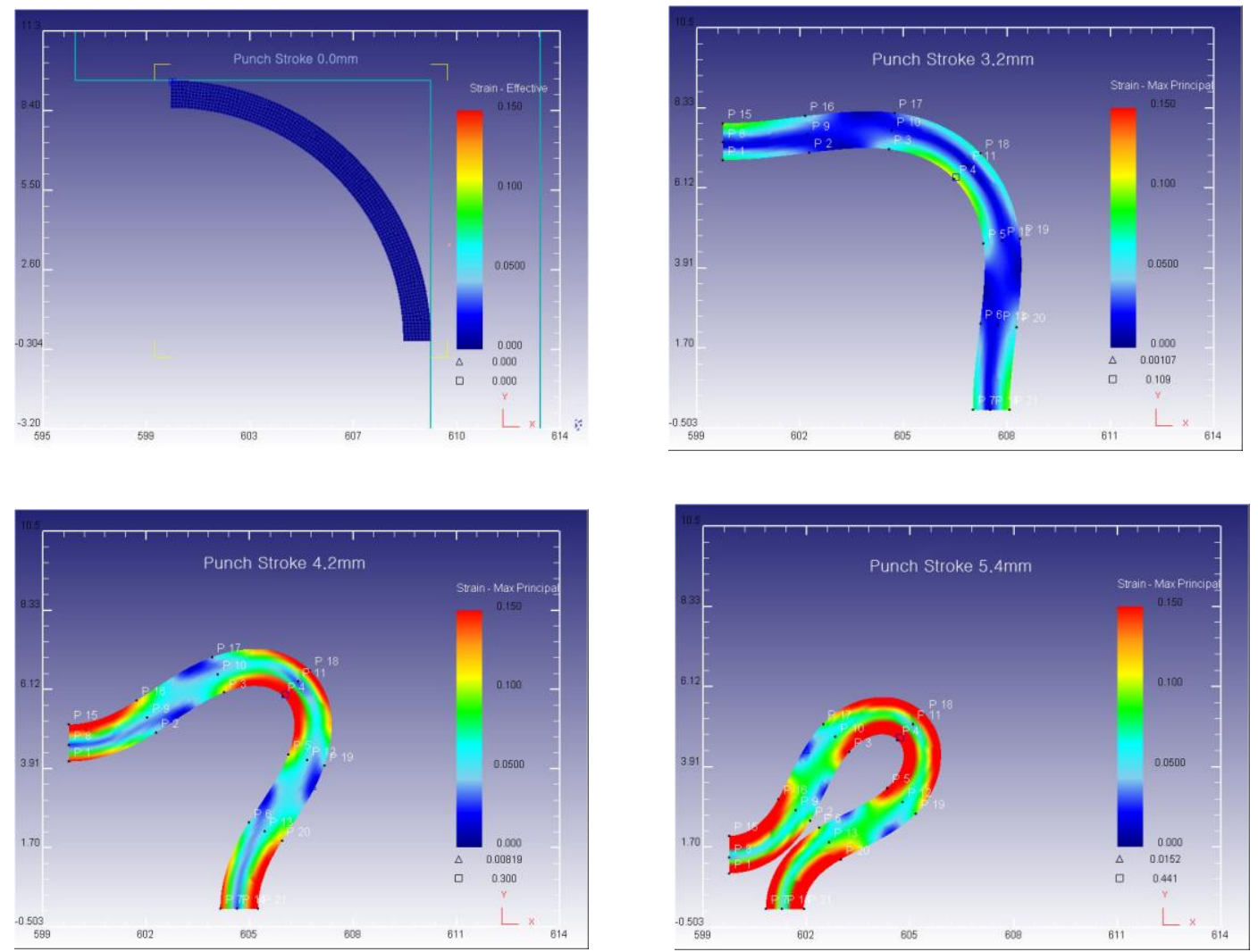

Fig.11 The result of deformation analysis by Deform-2D

지점에서 2차 하중 상승이 나타나지만, 경계가 뚜 렷하지 않다. 스트로크 $2.7 \mathrm{~mm}$ 지점에서 원형관은 4 각형상으로 되고, 2 차 하중 증가는 완만하게 나타나 는 특징을 볼 수 있다.

스트로크 $3.3 \mathrm{~mm}$ 부근에서 1 차 최대 하중이 나 타나고, 윤활유의 점도가 낮을 수록 약간 높은 하 중을 나타내고 있다. 스트로크 $3.3 \mathrm{~mm}$ 부근을 지 나면 원형관은 내측으로 더욱 좌굴되어 1 차 하중 감소를 나타낸다. 스트로크 $4.6 \mathrm{~mm}$ 부근에서 원형 관은 내측 4점 접촉 상태가 되어 급격하게 3 차 하중 증가를 나타낸다. 3 차 하중 증가의 시작은 거의 같은 시점이고 점도가 낮을수록 약간 높은 하중을 나타내고 있다.

Fig. 10 은 압축속도 $450 \mathrm{~mm} / \mathrm{min}$.조건에서 윤활유 의 종류를 다르게 한 실험 결과이다. 원형관에 접 촉되어 스트로크 $0.7 \mathrm{~mm}$ 부근까지 1 차 하중 증가 를 나타낸다. 여기서도 윤활유에 따른 압축하중의 차이는 아주 작게 나타나고 있다. 스트로크 $0.7 \mathrm{~mm}$ 에서 2 차 하중 상승이 나타나지만 경계는 뚜렷하
지 않다. 스트로크 $2.7 \mathrm{~mm}$ 지점에서 원형관은 4 각 형상으로 되고 2 차 하중 증가는 완만하게 나타나 고 있다. 스트로크 $3.3 \mathrm{~mm}$ 부근에서 1 차 최대 하 중이 나타나고 있다. 스트로크 $3.3 \mathrm{~mm}$ 부근을 지 나면 원형관은 내측으로 더욱 좌굴되어 1 차 하중 감소를 나타낸다. 스트로크 $4.6 \mathrm{~mm}$ 부근에서 원형 관은 내측 4 점 접촉 상태가 되어 급격하게 3 차 하중 증가를 나타낸다. 3 차 하중 증가의 시작은 거의 같은 시점이고 점도가 낮을수록 약간 높은 하중을 나타내고 있다.

이상과 같이 점도가 다른 5 종류의 윤활유와 5 종류의 압축속도에 따른 실험결과를 살펴보면 1 차 하중 증가에서 원형관이 4각형상이 되기 전의 하중상태는 어느 윤활유의 효과가 좋다고 판단하 기 어려운 결과이다. 그러나 1 차 최대 하중 점부 터는 전반적으로 높은 점도의 윤활유가 낮은 압 축하중을 나타내고 있다. 따라서 점도가 높은 윤 활유가 고압축 윤활에 효과적이라는 사실과 잘 일치한다[6]. 그러나 원형관의 2축압축 변형특성은 


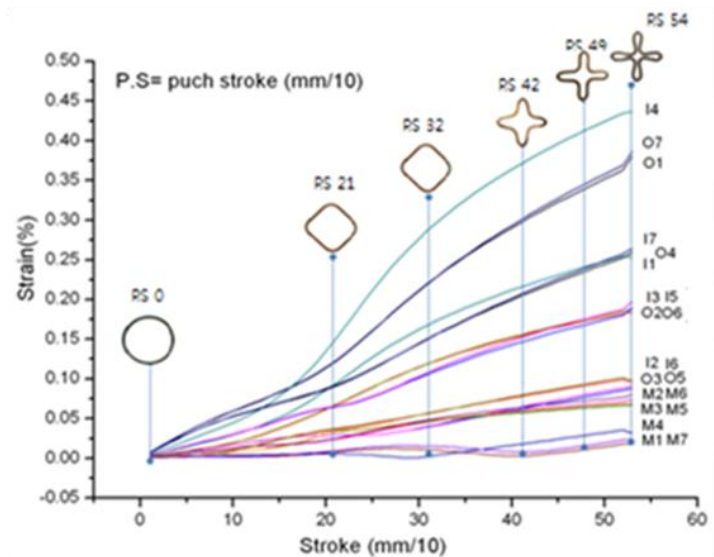

Fig.12 The relationship between the strain by Deform-2D analysis and deformed specimen shape under punch stroke

평면 접촉이 적고 점 접촉이 많으므로 윤활유에 의한 영향보다는, 압축속도의 영향이 더 크게 작 용함을 확인 할 수 있었다.

Fig. 11은 Deform-2D에 의한 변형 해석 결과를 나타낸 것으로 Fig. 5의 2축압축 실험 결과의 각각 의 변형 단계에서 나타나는 단면 형상 변화와 잘 일치하며, 변형 과정에서의 변형량과 응력상태를 알 수 있다.

Fig. 12는 2축 압축 변형 전 및 변형 시작단계에 서 종료시까지의 각 단계에서 Fig. 4의 $\mathrm{Al}$ 원형관 의 외측, 중립측, 내측의 각각의 위치에서 발생한 변형량의 크기를 나타낸 것이다.

Fig. 13은 2축 압축 실험결과 변형 전과 변형 시 작단계에서 종료시 까지의 각 단계에서 $\mathrm{Al}$ 원형 관의 외측, 중립측, 내측의 위치에서 측정한 마이 크로비커스 경도값을 나타낸 것이다. 이 결과 변 형전의 평균 경도값 $(89.3 \mathrm{Hmv})$ 에 대해 변형 최종 단계의 외측(O4) 및 내측(I4)의 최대변형이 발생한 위치에서의 경도값은 각각 $96.2 \mathrm{Hmv}$ 및 $97.7 \mathrm{Hmv}$ 의 값을 나타내고 있다.

이 결과는 변형이 크게 발생한 곳은 변형 경화 에 의해 경화 정도가 커진 것을 의미하므로 경도 값도 크게 나타나는 것을 확인하였다.

\section{4. 결 론}

본 연구는 2축 압축을 받는 $\mathrm{Al}$ 원형관의 변형특 성을 검토하기 위하여 단동 2 축 압축시험 금형을 제작하고, 압축속도의 크기와 윤활유의 종류에 따
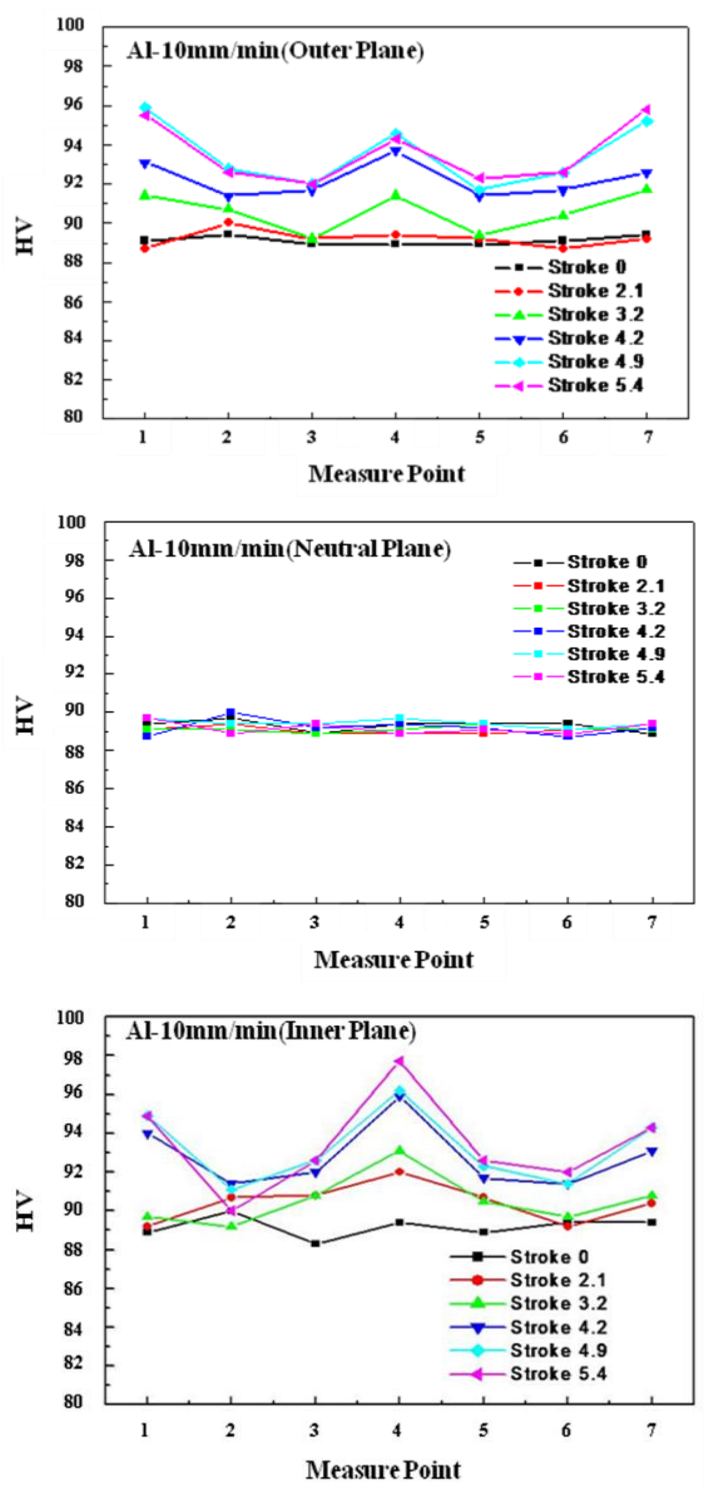

Fig.13 The result of micro Vickers hardness value at deformed stage

른 2축 압축 변형 특성을 검토하였다.

(1) 2 축 압축을 받는 $\mathrm{Al}$ 원형관의 응력-변형율 특 성은 압축속도의 크기에 따른 충격 반력의 영향에 의한 차이를 명백히 확인할 수 있었고, 압축속도가 증가할 수록 운동에너지도 커지므로 압축 하중이 낮아지고, 압축변형 스트로크가 작아지는 특이성을 확인하였다.

(2) 원형관의 경우는 평면접촉이 적고 점 접촉 이 많으므로 윤활유에 의한 영향은 크게 나타나지 
않음을 확인 할 수 있었다.

(3) Deform-2D를 이용한 변형해석 결과와 실험결 과도 어느 정도 잘 일치하고 있음을 알 수 있었고, 원형관의 대-소성변형에 따른 경도값의 차이도 일 관되게 나타나는 것을 확인하였다.

\section{후 기}

본 논문은 서울과학기술대학교 학술연구비의 지 원에 의해서 수행된 연구로 이에 감사 드립니다.

\section{참 고 문 헌}

[1] M. Gotoh, Y. Shibata, 1990, Elastic-Plastic Analysis of Uni-Lateral and Bi- Lateral Compression of A Circular cylinder by Flat Plates, J. Soc. Mech. Eng. Int. J. Ser. A, Vol. 56, No. 529, pp. 2002 2010.
[2] M. Gotoh, C. K. Yoo, 1992, Proc. The 43rd JSTP joint Conf., Jpn. Soc. Technol. Plast., Kyoto-shi, Japan, pp. 561 564.

[3] M. Gotoh, C. K. Yoo, S. Kaneko, M. Yamashita, 1997, Proc. JSTP 1997 Spring Conf., Jpn. Soc. Technol. Plast., Chiyoda-shi, Japan, pp. 281 282.

[4] S. T. Won, C. K. Yoo, K. J. Kim, W. K. Kim, M. Gotoh, K. T. Kim, H. J. Kim, T. H. Kim, 2009, Proc. KSPE Spring Conf., Kor. Soc. Precis. Eng., Jejudo(Ramada Plaza Hotel), Korea, pp. 733 744.

[5] S. T. Won, C. T. Kim, C. K. Yoo, K. J. Kim, W. K. Kim, J. J. Yoo, 2010, Proc. KSPE Spring Conf., Kor. Soc. Precis. Eng., Jeju-do(Ramada Plaza Hotel), Korea, pp. 1167 1168.

[6] E. Rabinowicz,1995, Friction and Wear of Materials, John Wiely \& Sons, Inc., N.Y., pp. 261 263. 